\title{
Pulse Electric Field Technology for Wastewater and Biomass Residues' Improved Valorization
}

\author{
Andrea G. Capodaglio
}

Citation: Capodaglio, A.G. Pulse Electric Field Technology for Wastewater and Biomass Residues' Improved Valorization. Processes 2021, 9, 736. https://doi.org/10.3390/ pr9050736

Academic Editor: Jorge A. Ferreira

Received: 7 April 2021

Accepted: 19 April 2021

Published: 22 April 2021

Publisher's Note: MDPI stays neutral with regard to jurisdictional claims in published maps and institutional affiliations.

Copyright: (C) 2021 by the author. Licensee MDPI, Basel, Switzerland. This article is an open access article distributed under the terms and conditions of the Creative Commons Attribution (CC BY) license (https:/ / creativecommons.org/licenses/by/ $4.0 /)$.
Department of Civil Engineering \& Architecture, University of Pavia, 27100 Pavia, Italy; andrea.capodaglio@unipv.it

\begin{abstract}
Development and adoption of more efficient and robust technologies for reuse of wastewater embedded resources, in particular materials and energy, is becoming an unavoidable necessity. Among many emerging technologies in the sector of wastewater treatment residuals valorization, Pulsed Electric Field (PEF) processes have shown interesting potential, although they have not yet entered the sector's mainstream as a consolidated commercial technology, as in other industrial applications, such as the food, medical, and bio-based industries. PEF is a non-thermal technology suitable to biological applications, involving gentle cell disintegration and enhanced cell membrane permeability and as such applicable to disinfection, sterilization, and to those processes that benefit from an enhanced extraction of organic compounds from biological matter, such as anaerobic digestion, biological processes for recovery of nutrients, and biorefinery of cell-embedded compounds. PEF technology applications in wastewater/biomass residues management are reported and advantages, drawbacks, and barriers of the technology are discussed in this paper.
\end{abstract}

Keywords: pulse electric field; wastewater; wastewater sludge; energy; materials recovery; circular economy; sustainable technology

\section{Introduction}

Increasing pressure towards the adoption of sustainable, Circular Economy schemes in all sectors of modern society, is prompting development and adoption of more efficient and robust technologies for reuse of wastewater embedded resources, in particular materials and energy [1,2]. Among many emerging technologies in the sector of wastewater treatment, in particular for the valorization of wastewater treatment residuals including sewage sludge, Pulsed Electric Field (PEF) processes have recently shown interesting potential, although they have not yet entered the mainstream in this sector as a consolidated commercial technology.

PEF processing is a growing electro-magnetic technology already employed in medical [3], food [4], and bio-based [5] industries. PEF technology has received increasing attention in past decades for the extraction or insertion of molecules and proteins into cell membranes, to achieve nonselective increase of drugs or genetic material in cells, to fuse cells with tissues, to induce intracellular effects such as the release of calcium, and modify texture and physical properties of plant tissues [6]. PEF is based on the application of high intensity $(>0.1 \mathrm{kV} / \mathrm{cm})$ and short duration (micro- to nano- seconds) electric fields to a biological matrix positioned between two electrodes, leading to electroporation (sometimes called electropermeabilization) of cell membranes. Electroporation is defined as the modification of cell membranes' permeability through the generation of nanometer-size pores, after exposing them to a strong electric field. Electroporation leads to increase in their permeability to ions, water, and other molecules.

Among the many current applications, PEF is recognized as a promising non-thermal technology for food preservation, since it allows maintaining foodstuff properties while inactivating vegetative bacteria and yeasts. Its use for pasteurizing milk, juices, or other 
liquid food products is now common, while other applications, particularly those related to its potential for mass transfer improvement (e.g., increasing of the yield of vegetable oils and polyphenols extraction, accelerating drying rates or improve industrial processing of fried vegetables), are being implemented in solid foods processing [4]. Such developments and improved understanding of the mechanisms and impact of this processing technology on biological cells suggest that PEF could become an important tool for improvement of energy-efficient biosolids exploitation technologies.

The PEF process is based on the creation of a potential difference across a conductive biological material placed between two electrodes; this creates an electric field which intensity depends on applied voltage, shape of electrodes, and distance between them. Electroporation occurs due to the thus induced transmembrane potential [7]. In conventional PEF processing the electric field is applied in intervals in the range of micro- to milliseconds; in nanosecond PEF (nsPEF) processing, much higher electric fields $(10-100 \mathrm{kV} / \mathrm{cm})$ are applied for intervals of 1-300 ns, inducing distinct intracellular effects from those of conventional PEF [8]. In both cases, the resulting electroporation increases mass transfer of cell-bound molecules and ions, giving rise to promising applications in diverse fields of biotechnology (e.g., extraction of cellular compounds, stimulation of cell growth, and microbiological inactivation). The size and persistence of pores created by electric pulses depends on pulse duration: short (e.g., $100 \mu \mathrm{s}$ ) duration pulses create smaller pores than longer (e.g., $2 \mathrm{~ms}$ ) pulses. For practical applications, it is important to determine not only the size and number of pores created by pulses, but also how long they will remain open. It could be expected that larger pores would need more time to reseal, as experiments on mouse plasma cells showed that the original impermeability of the membrane subject to $100 \mu \mathrm{s}$ pulses was restored after about 6-7 $\mathrm{min}$, while resealing was slower (15-20 min) when the same cells were exposed to 2 ms pulses. Multiple repeated short pulses increase pore number, compensating the smaller size of the pores created [9]. By adjusting process parameters, the desired degree of electroporation for a specific effect may be achieved and controlled.

PEF technology is suitable to biological applications involving gentle cell disintegration and cellular compounds extraction processes. Electroporation induced by PEF processing results in increased extraction yields of cell-derived compounds such as carbohydrates, proteins, and lipids, and water elimination without loss of cell integrity [10] by diffusion gradient-assisted release. While PEF processing permeabilizes cell membrane, it does not cause its complete disruption, as in other processes (e.g., microwaves); this limits the extraction of cell-bound compounds on one side, but does not impede cells growth [11], giving highly promising perspectives in future biotechnological applications. Controlled biological growth stimulation has been achieved under nsPEF processing for various organisms treated with $100 \mathrm{~ns}$ pulses at electric fields of $10 \mathrm{kV} / \mathrm{cm}$ under strict process characterization and control [12]: photoautotrophic Arthrospira platensis and Chlorella vulgaris and heterotrophic Saccharomyces cerevisiae showed increase in biomass concentrations between 13 and $20 \%$ under those conditions [13].

On the other hand, if the electric field is strong enough, and pulse duration is long enough, cell membranes can be irreversibly damaged, and the exposed organisms will die. For example, PEF technology was applied to the disinfection of combined sewer overflow (CSO) discharges by inducing 5-9 log pathogen cells destruction with 1-10 ms pulses at $1-35 \mathrm{kV} / \mathrm{cm}$ fields [14]. In addition to disinfection and sterilization, PEF technology's specific applications in wastewater/biomass residues management have been tested to enhance conversion of organic solids into biogas via anaerobic digestion [15], enhancement of bacterial processes activity [16], and extraction of biofuel precursors [17].

This paper reviews actual and potential applications of PEF electroporation technology for the creation of improved wastewater and biomasses residuals management schemes. 


\section{Fundamentals of Pulsed Electric Field-Induced Electroporation}

Notwithstanding the established industrial applications of PEF technology, there are still notable gaps in the understanding of the electroporation phenomenon. Current understanding is based on the dielectric breakdown theory, which considers a selective damage of biological membranes. These consist almost entirely of cholesterol and phospholipids, which are composed of polar glycerol (hydrophilic) and nonpolar hydrophobic hydrocarbon parts. Within the membrane, the latter are oriented inwards, polar heads outwards, making this structure almost impenetrable for polar molecules. Under certain conditions (i.e., high temperature and/or surface tension) water and monoatomic ions may permeate them due to the temporary formation of very small, unstable pores in the lipid layer, which may become more stable under an external electric field acting on the membrane [18].

Biological cell membranes, filled with low permittivity dielectric material, could be considered as capacitors, maintaining an electrochemical gradient on both sides due to the accumulation of negative ions at the inner surface, and the presence of an equal number of positive ions outside. This builds a transmembrane potential ("resting potential") across the membrane wall. After exposure to an external electric field of sufficient intensity, ions within the membrane migrate toward the outside, with accumulation of free charges at both sides of the wall, increasing the potential difference across the membrane. The additional transmembrane potential induced by the electric field, larger than the natural one, is unevenly distributed over the membrane surface. Upon locally reaching a critical threshold value $\left(E_{c}\right)$ of overall transmembrane potential (sum of the externally induced and resting potentials), breakdown of the cell membrane (i.e. electroporation) occurs with formation of micropores that increase permeability and may eventually result in membrane rupture [19], as schematized in Figure 1.

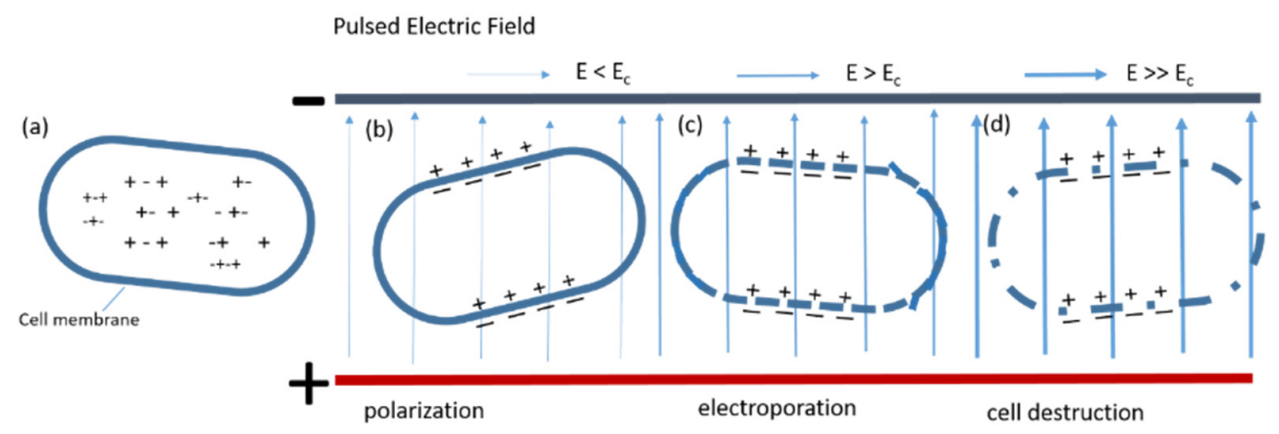

Figure 1. Mechanism of PEF action.

The final effect on a specific membrane wall, therefore, depends on the strength of the electric field and intensity of treatment, making the membrane rupture reversible or irreversible. The phenomenon is reversible if the increase in permeability is temporary, and the wall returns to the initial conditions upon termination of its exposure to the electric field, evolving along pore formation, expansion, and resealing phases. Such a process is mostly used in biotechnology applications (e.g., for DNA transfer into bacterial cells). Breakdown is irreversible if the cell dies due to prolonged, high exposure to the electric field. The critical intensity of electric field in both cases is influenced by process parameters, cells' physical-chemical parameters (conductivity, extracellular medium ionic composition, density, osmotic pressure, and others), and conformation (type, size, shape) [20]. Process operating parameters for electric field strength are: treatment time, pulse shape and width, number of pulses, specific energy input, and repetition frequency. All these must be adjusted according to the nature of the substrate under treatment and the desired effect. Generally, larger pulse widths increase tissue disintegration at constant pulse number, and larger number of pulses at shorter widths result in greater efficiency at constant total treatment time. Lower frequencies result in greater disintegration at constant pulses number [21]. A PEF system usually consists of a high voltage power source, a function 
generator, a switch circuit, and a proper treatment chamber. A commercial, tube-type PEF apparatus is shown in Figure 2. Design of PEF systems was addressed by Kovacic et al. [22].
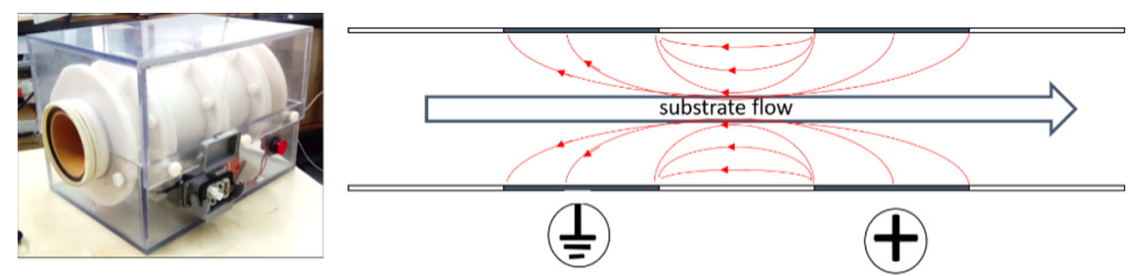

Figure 2. PEF tubular prototype apparatus, and scheme of working principle.

\section{PEF Application Areas in Wastewater and Biomass Residuals Valorization}

Wastewater treatment biological residuals (sewage sludge) consist of excess biomass produced during biological treatment processes. Sludge matter contains organic matter, nitrogen, phosphorus, micronutrients, and some residual contaminants (pathogenic organisms, toxic metals, recalcitrant organic compounds). Methods for safe sludge disposal incur considerable costs (they may contribute $30-50 \%$ of the total operation costs of wastewater treatment processes [23]) and may cause considerable environmental impacts [24]. On the other hand, waste sewage sludge still contains valuable resources, like nutrients and energy, that can be recovered through a variety of approaches.

In recent years, a new class of mixotrophic wastewater treatment processes based on algal cultures, where light and $\mathrm{CO}_{2}$ are utilized in addition to organic carbon compound for biomass growth, has been increasingly studied. The interest in algae as production organisms in wastewater treatment is not only due to the fact that algae-based systems can simultaneously remove BOD, $\mathrm{N}$, and $\mathrm{P}$, but also to potential substantial advantages compared to traditional bacterial systems in biofuel production and $\mathrm{CO}_{2}$ emissions mitigation [25], and as feedstock in biorefineries, or other applications [26].

Waste lignocellulosic biomass (LCBs) from plants and crop residues is a globally available, abundant, and potentially carbon-neutral sustainable feedstock containing sugarrich platforms. LCB is already widely used for biogas production and may be converted to other biofuels or originate recovery of specialty products by biorefinery. The nature of the lignin-polysaccharide matrix, however, makes it recalcitrant to biodegradation and compounds extraction [27]. The identification of proper pretreatments is therefore an essential step in LCB energy conversion and materials recovery.

This section summarizes significant reported experiences in the use of PEF technologies in resources recovery from wastewater-originated biomass residues, as depicted in Figure 3.

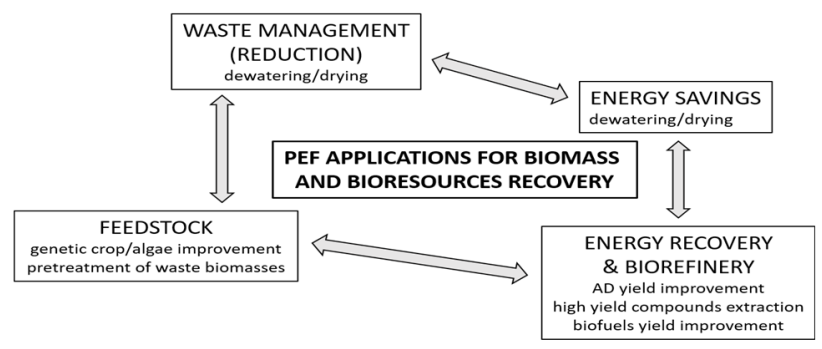

Figure 3. Possible PEF applications for biomass and bioresources recovery.

\subsection{Biomass-to-Biogas Generation Improvement}

Wastewater sludge and biomasses treatment practices emphasize the use of biosolidsembedded chemical energy for the recovery of usable energy forms. Of particular interest is the generation of methane-rich biogas through the fermentation of organic materials by bacteria in anaerobic digestion (AD) processes, one of the mainstream sludge processing technologies from the perspective of energy recovery. Wastewater sludge (including mixed 
algal-cell biological substrates), as well as other biomasses, such as waste-grown microalgae and lignocellulose are considered biofuel feedstock to all effects, with high potential for biogas generation. While $\mathrm{AD}$ is a standard application for biogas production from sludge in biological wastewater treatment facilities, there are more than 7000 algal wastewater treatment ponds systems in the US alone, and these could potentially yield as much as 0.25-0.50 $\mathrm{L} \mathrm{CH}_{4} / \mathrm{g}$ VS when treated with an 11-day HRT mesophilic AD [28]. Combined activated sludge/algal culture facilities are also being designed and operated to treat domestic wastewater to take advantage of synergic effects of $\mathrm{CO}_{2}$ uptake, $\mathrm{O}_{2}$ production, and methane generation from $\mathrm{AD}$ of residuals [29]. In addition, with proper pretreatment focused on improving cellulose and hemicellulose accessibility, lignocellulosic biomasses (LCBs) chemical energy could also be converted to biogas.

Biogas, among the other renewable biofuels, is easily applicable to static and mobile uses [30] and is targeted by European policies as a key component of sustainable circular economy [31]. For AD to be efficient, ready availability of organics contained in the substrate mixture to the bacterial archea contributing to the process is critical, yet most organics are initially contained within substrate cells or complex macromolecules in the process feed and often not readily accessible to microorganisms. Many pretreatment methods have been investigated to enhance AD biogas production with minimal economic costs, energy consumption and without adverse environmental impact. Ideally, an optimal pretreatment process should require no or minimal heating (to minimize energy input), not include chemicals' addition, and entail short processing times (to avoid the need for large reactors).

Solubilization (hydrolyzation) of organic compounds in cells has been indicated as one of the most common process rate-limiting steps [32,33]. During hydrolyzation, high molecular weight organic compounds (proteins, carbohydrates, and triglycerides) are degraded into simpler molecules (amino acids, monosaccharides, disaccharides, fatty acids) that are thus made available for subsequent degradation. Different solubilization methods such as thermal, mechanical, chemical, irradiative, biological, or combinations thereof, are therefore often employed prior to an AD process. Biological hydrolyzation enhancement requires larger reaction volumes in the $\mathrm{AD}$ line [32]. Among recently proposed technologies, microwave (MW) irradiation can enhance hydrolyzation by sludge disintegration; however, major disadvantages of the MW destruction method are the high energy consumption and equipment costs, possibly resulting in a negative overall energy balance (methane produced minus energy appli6ed for pretreatment) of up to $300 \mathrm{kWh} /$ ton sludge [34]. Subsequent studies showed that, in order for MW irradiation be effective, additional sludge pretreatment (e.g., chemical deflocculation with sodium citrate, or others) could be required prior to it [35].

PEF is considered a non-thermal process (due to Ohmic heating effects, temperature usually does not exceed $40^{\circ} \mathrm{C}$ ) [36], indicated as effective in accelerating the hydrolysis step, since the effect of the electric field on raw substrates leads to the increase of bioavailability of entrapped organic compounds, leading in turn to more efficient AD at shorter sludge retention times when applied as a pretreatment step [37].

The earliest studies concerning PEF application method in biogas production improvement are relatively recent (early 2000s). Earlier studies investigated the process' effect on the release of dissolved organic carbon (DOC) from biological sludge and COD uptake, and the impact of treatment intensity on the conversion of solids and refractory organics to more bioavailable soluble and colloidal forms (readily biodegradable COD, rbCOD). It was shown that methanogenic conversion increased consistently ( $80 \%$ for pig manure, $100 \%$ for waste sludge) at hydraulic retention time (HRT) between 25 to 30 days, with process application intensities up to $40 \mathrm{kWh} / \mathrm{m}^{3}$ [15]. PEF pretreatment at levels of $34 \mathrm{kWh} / \mathrm{m}^{3}$ increased methane by $33 \%$ and COD removal up to $18 \%$ while $\mathrm{CH}_{4}$ production from co-digestion of landfill leachate and agro-food industry slurry increased by up to 44 and $8 \%$ with treatment at 50 and $15 \mathrm{kWh} / \mathrm{m}^{3}$, respectively. COD removal efficiency increased by up to $100 \%$ for landfill leachate, and $17 \%$ for fruit/vegetable slurry, compared to non-preprocessed sub- 
strate [38]. These results are comparable to those obtained by preprocessing sewage sludge with ultrasonication (US) or MW, which achieved biogas production improvement of $27 \%$ and 20\%, respectively. An energy balance of the entire process, however, showed in both cases a negative net energy production of $-15.3 \mathrm{kWh} / \mathrm{t}$ and $-18.1 \mathrm{kWh} / \mathrm{t}$, respectively, indicating that both processes were not energetically sustainable [39].

PEF has also been tested in algal AD's biogas production: Chlorella vulgaris was subjected to PEF intensity in the range $2-150 \mathrm{kWh} / \mathrm{m}^{3}$ with maximum solubilization of soluble COD improving to $>830 \%$ and enhancement in biogas production of around $27 \%$ at process intensity of $5.4 \mathrm{kWh} / \mathrm{m}^{3}$, which increased by as much as $110 \%$ at $35 \mathrm{kWh} / \mathrm{m}^{3}$ [40].

PEF applications to LCB for biogas production enhancement are not many, mostly at laboratory scale; however, all studies showed an enhancement of $\mathrm{CH}_{4}$ production and a positive energy balance. Lindmark et al. evaluated PEF technology pretreatment for improving biogas production from ley crop silage with batch AD. $\mathrm{CH}_{4}$ yield increased by $16 \%$, at $30 \%$ reduced digestion time in comparison to untreated substrate at electric filed application of $96 \mathrm{kV} / \mathrm{cm}$ [41]. Energy balance showed that the pretreatment produced twice the output (in the form of methane) compared to the electrical energy input.

PEF pretreatment of hybrid Pennisetum stems induced superior biogas production efficiency, higher cumulative biogas production (by $27 \%$ ), and maximum $\mathrm{CH}_{4}$ concentration in biogas [42]; pretreatment of harvest residues enhanced both biogas and $\mathrm{CH}_{4}$ yield by 18 and $16 \%$, respectively, in corn stalks $(\mathrm{E}=0.935-1.664 \mathrm{kV} / \mathrm{cm}$ for $10 \mathrm{~min}), 18$ and $17 \%$, respectively, in soybean straw after pretreatment $(\mathrm{E}=0.760-1.354 \mathrm{kV} / \mathrm{cm}$, duration $30 \mathrm{~min})$ in soybean straw. The calculation of the energy balance showed the highest energy gains from pretreated AD substrates of $13.30 \mathrm{kWh} / \mathrm{t}$ for corn stalks, and of $14.95 \mathrm{kWh} / \mathrm{t}$ for soybean straw [43].

Comparison among different pretreatment methods (freezing, alkaline or acid treatment, ultrasounds, and PEF) on AD biodegradability of the LCB components of grape pomace in terms of $\mathrm{CH}_{4}$ production in large scale, continuous mode digesters showed that PEF resulted in maximum increase of cumulative $\mathrm{CH}_{4}$ yield of $4 \%$, and hydrolysis constant increase by $14 \%$, although it did not give the best overall results [21]. Table 1 summarizes PEF applications for biogas production augmentation from various biomasses.

Table 1. Reported PEF application in biogas augmentation from various biomasses.

\begin{tabular}{|c|c|c|}
\hline Feedstock & Description & Reference \\
\hline $\begin{array}{l}\text { Sewage sludge, } \\
\text { Pig manure }\end{array}$ & $\begin{array}{l}\mathrm{E}=24.5 \mathrm{kV} / \mathrm{cm}, \mathrm{HRT}=0.01 \mathrm{~s}, \mathrm{TI}=4.0-19.8 \mathrm{kWh} / \mathrm{m}^{3} . \\
\text { Solubilized } \sim 10 \% \text { of total COD, soluble COD increased from } \sim 20 \text { to } \\
>1000 \mathrm{mg} / \mathrm{L} . \text { Increased methane production after } 25-30 \text { days: } 80 \% \\
\text { for pig manure, up to } 100 \% \text { for WAS. }\end{array}$ & [15] \\
\hline Landfill leachate and vegetable slurry & $\begin{array}{l}\qquad \mathrm{E}=20 \mathrm{kV} / \mathrm{cm} ; \mathrm{TI}=15,30,50 \mathrm{kWh} / \mathrm{m}^{3} \text {. } \\
\mathrm{CH}_{4} \text { production from landfill leachate increased up to } 44 \% \text { and COD removal } \\
\text { by } 100 \% \text { at the highest TI, production from vegetable slurry increased by } 7 \% \\
\text { at lowest TI, with COD removal of }+17 \% \text {. }\end{array}$ & [37] \\
\hline $\begin{array}{c}\text { Sludge (primary }+ \text { secondary) from } \\
\text { wastewater } \\
\text { treatment }\end{array}$ & $\begin{array}{l}\mathrm{TI}=30.0-35.8 \mathrm{kWh} / \mathrm{m}^{3} \text {. } \\
\mathrm{CH}_{4} \text { production increased by } 33 \%, \mathrm{COD} \text { removal by } 18 \% \text {. }\end{array}$ & [38] \\
\hline Biological sewage sludge & $\begin{array}{l}\qquad \mathrm{E}=5.88 \text { to } 14.7 \mathrm{kV} / \mathrm{cm} \text {, Energy input }=150-280 \mathrm{~kJ} / \mathrm{L} \text {. } \\
\text { Pretreatment efficiency increased with E level. Increase of T also increased } \\
\text { pretreatment efficiency. }\end{array}$ & [44] \\
\hline $\begin{array}{l}\text { Biological sludge ( } 60 \% \text { WAS, } \\
40 \% \text { primary) from WWTP }\end{array}$ & $\begin{array}{l}\qquad \mathrm{E}=8 \text { to } 30 \mathrm{kV} / \mathrm{cm} \text {. } \\
\text { Biogas yield improved by up to } 20 \% \text {, and reduced sludge foaming during AD. }\end{array}$ & [45] \\
\hline Thickened WAS & $\begin{array}{c}\mathrm{V}=20 \mathrm{kV} \text { (coaxial and multiple ring electrodes) } \\
\text { Biogas yield increased by } 150 \% .\end{array}$ & [46] \\
\hline Primary WWTP sludge & $\begin{array}{c}\mathrm{V}=30 \mathrm{kV} ; \mathrm{TI}=33 \mathrm{kWh} / \mathrm{m}^{3} \text {. } \\
\text { Increased } \mathrm{AD} \text { production of } \mathrm{CH}_{4} \text { by } 8 \% \text {, of VFAs by } 7 \% \text {. }\end{array}$ & [47] \\
\hline
\end{tabular}


Later studies investigated PEF pretreatment impact on the anaerobic microbiodome's structure and function following the observation of methanogenic generation increase. Results showed significant shift in phylotypes after pretreatment (e.g., increase of Deltaproteobacteria and Spirochaetes; Methanoculleus decreased from 66\% to 32\%, and Methanosaeta increased from $22 \%$ to $55 \%$, leading to more efficient acetate utilization) within the digester [48]. Subsequent research also revealed that PEF-pretreated anaerobic sludge consisted of more highly diversified bacterial community, the activity of which was stimulated by the presence of more bioavailable organic matter [49].

The optimization of the process focuses on economic aspects, i.e., the additional biogas yield compared to additional energy consumption, reduction of HRT, leading to smaller AD reactors, and final amounts of digested biosolids. Optimization, however, is a challenging task due to many variables and parameters involved, previously described in Section 2, which can significantly influence the final outcome in terms of improved methane yields. Process parameters must therefore be chosen with specific consideration to each individual condition (substrate characteristics, reactor type, and expected effects).

\subsection{Enhanced Phosphorous Recovery}

Phosphorus $(\mathrm{P})$ is a finite, irreplaceable resource extracted from a non-renewable mineral (phosphate rock); the rise of global population and living standards expectations is anticipated to drastically increase the demand for phosphorus due to the unavoidable need to produce more food for humanity. Current studies suggest that the world may deplete the known available phosphorus reserves in less than 300 years from now [50].

About $16 \%$ of mined $\mathrm{P}$ ends up in the human diet, and eventually in their excreta, therefore wastewater and excess biological sludge, where P content may reach up to 7-10\% of the total solids under an extended biological P removal process (EBPR) [51], show great potential for P recovery. Chemical precipitation recovery [52] is an established process for producing phosphorus-containing minerals, such as struvite and other bioavailable $\mathrm{P}$ compounds from wastewater [53] and wastewater residues [54], which would be suitable for reuse in the fertilizer industry. Release of cell-immobilized P into solution, leading to subsequent crystallization, is the limiting step in these processes. Cell-stored P can be released by anaerobic fermentation, hydrolysis, or various pretreatments that disrupt the cells' structure, either physically (e.g., heat, irradiation, sonication), chemically (e.g., acid/alkali attack), or by combinations of the above. Among physical processes, PEF can not only break the floc structure, but also the cell membrane to promote the release of cell-contained substances, including phospholipids [16]. The specific release mechanism of $\mathrm{P}$ forms under PEF treatment was investigated by $\mathrm{Hu}$ et al., pulsed discharge voltage of $40 \mathrm{kV}$, pulse frequency of $400 \mathrm{~Hz}$, and forming capacitance of $4 \mathrm{nF}$, with electrodes separation distance of $5 \mathrm{~mm}$ were used [54]. Compared with raw sludge, PEF-pretreated sludge significantly enhanced the release of poly-P, indicating ongoing electroporation of cell membranes. Tests indicated that $P$ release could be enhanced by $26.7 \%$ as soluble ortho$\mathrm{P}$ by PEF followed by anaerobic fermentation, compared to fermentation alone, with PEF contributing $42.2 \%$ of the additional total soluble ortho-P increase. It was also shown that the release of poly-P from sludge could be enhanced by destruction effect of the sludge flocs occurring within the process. Total suspended solids removal rates of $23.8 \%$ and $34.3 \%$ of volatile suspended solids, respectively, were determined for the PEF-pretreated solid phase, suggesting that soluble organics production and sludge reduction were also enhanced by the process. The process' energy demand was determined as $0.12 \mathrm{kWh} / \mathrm{L}_{\text {treated, achieving }}$ specific dissolution of $157.5 \mathrm{mg}$ P. Compared to other pretreatment processes, PEF had superior $\mathrm{P}$ release efficiency than microwave irradiation (which induced $\mathrm{P}$ release of $50 \mathrm{mg} \mathrm{P} / \mathrm{L}$ ), which required similar investment costs and higher energy consumption than $\mathrm{PEF}$, and acid/alkali pretreatment (with release effect of $60 \mathrm{mg} / \mathrm{L}$ at $\mathrm{pH}=10$, and $120 \mathrm{mg} / \mathrm{L}$ at $\mathrm{pH}=3$, respectively) [54]. Although conceptually simpler and less time consuming, chemical destruction involves high chemical costs and the increased risk of corrosion to process equipment. 
PEF processing for release of sludge cells' stored phosphorus has some other important advantages compared to the different conventional methods applied: for example, heavy metals and other pollutants in the sludge do not pass into solution (acidification is not applied), hence pre-treatment for their removal prior to struvite precipitation is not required. Appropriate solution conditions for optimal removal are however necessary and could require sophisticated assays for proper identification [55]. PEF may thus be considered a promising pretreatment for $\mathrm{P}$ recovery and for the reduction of sludge quantities.

\subsection{Sludge Dewatering and Volume Reduction}

As an essential aspect of sustainable sludge management, waste sludge volumes (and mass) should be minimized prior to further treatment or biosolids reuse. Various technologies have been developed to this purpose, which are applicable either in the liquid treatment or in the sludge processing lines [56]. Sludge has a complex composition, particularly with reference to extracellular polymeric substances (EPS), mainly composed of large molecules' bacterial secretions, deriving from cell lysis and molecular hydrolysis, with primary components consisting of proteins and polysaccharides. Many functional groups of these compounds can form strong hydrogen bonds with water molecules [57]. Incineration is a widely used disposal method for wastewater treatment residuals, and other thermal processes (gasification, pyrolysis, hydrothermal carbonization) are also used [58]. These can recover energy from the sludge's embedded components as heat, gas (py-gas), solids (biochar), or liquids (py-oil) [59], and other recoverable residuals, that may feed local Circular Economy circuits [60]. A severe technological limitation of these processes lies in the fact that the residuals' water content must be well below $30 \%$ (ideally, closer to $15 \%$ ) otherwise the energy required for water evaporation (theoretically $2270 \mathrm{~kJ} / \mathrm{kg}$ ) will significantly affect their energy balance. Hence, sludge dewatering methods that alter the composition and structure of EPS to promote easier release of bound water have been developed, including acid/alkali treatment, bioflocculants dosage, ultrasonic irradiation, heat, and pulse electric field treatment [61].

Effectiveness of the PEF process depends on achieving uniform packing of the treated medium (sludge or other) between electrodes, under proper conditions. An excessive presence of free high conductive liquid would increase electrical energy losses, but low values of external moisture could also limit the effect of the process due to lack of interparticle contact. Increase of PEF efficiency was observed after pre-compression of the substrate, with removal of some excess free liquid in the initial steps of the process: the applied pressure damages punctured cells, enhancing moisture migration and depressing cell resealing processes [62].

Low, direct current electric field applied to sludge also induces an electroosmotic flow phenomenon in the matrix; in turn, this promotes extra water removal from the sludge, increasing the final "cake" solids content. In addition, electrical field application induces electrokinetic phenomena in the matrix, such as electromigration and electrochemical reactions at the electrodes, and these also positively affect, directly or indirectly, dewatering as result of the release of intra- and extra-cellular constituents and bound water. PEF can thus be used as a preprocessing step in sludge dewatering, since disposal costs of dewatered sludge decrease proportionally to the decrease of water content. Reducing energy consumption for sludge dewatering (about $2500 \mathrm{kWh} /$ ton d.w.) is a key necessity for sludge disposal, in view of limitations foreseen for some current options, such as landfilling and land application [63], and the feasibility and efficiency of common alternative processes of sludge [64]. Return flow from PEF-dewatered sludge has significantly higher soluble rbCOD content, up to $160 \%$ more [15] than under normal process operation (e.g., centrifugation alone), and thus a higher recoverable energy content in AD processes. Since sludge disintegration technologies are also effective in pathogen inactivation, except for spores and viruses [65], dewatered sludge can be used for land applications where appropriate. 


\subsection{Sustainable Biorefineries}

The global market share of biofuels, including biodiesel, bioethanol, biogas, and biobuthanol, is expected to grow significantly in the next years, due to their lower negative environmental impact compared to fossil fuels, and to strong regulatory drives by most industrialized countries. In particular, the so-called 3rd biofuels generation, i.e., those derived from microalgae, is drawing particular attention since it became apparent that algae could be capable of much higher yields than other traditional feedstocks, producing oils (lipids) that can be easily refined into diesel, gasoline, and even jet fuel components by means of an array of technologies such as pyrolysis, dilution, micro-emulsification, transesterification, and others [15]. Chemical reaction of triglycerides and alcohol supported by catalysts such as sodium hydroxide is among the processes that can be used, which are referred to under the general term of biorefinery. In addition to biofuels production, microalgae showed to be a possible alternative source of proteins to meet future global protein requirements [66]. Microalgae, in fact, show a high content of valuable compounds such as lipids, proteins, polysaccharides, antioxidants and pigments (>50 g/100 g d.w.), have high biomass growth rate and productivity (three to five times higher than crops like corn, canola or soy), and they offer the possibility to be grown on non-fertile land (without competition for land with food crops), in controlled conditions, even using wastewater as substrate, in any season [67].

It has been postulated that an attentive biorefinery exploitation of a broader spectrum of microalgal constituents would enable a rapidly increasing growth of Green Economy, however, it has been pointed out that production costs should be reduced at least by an order of magnitude for algal products to be economically competitive [68]. Algal cultivation delivers algal solutions at $0.05-0.075 \%$ to $0.3-0.4 \%$ d.m. for open pond and closed systems, respectively. One of the greater limitations to the economic sustainability of these processes is related to algae drying and compounds extraction, which consume large amounts of energy and account for approximately 30\% of production costs [69]. Dewatering and drying technologies are usually adapted from similar wastewater sludge processes and include mechanical/physical methods (i.e., centrifugation, pressure, vacuum or membrane filtration, sonication, high pressure homogenization, microwave irradiation, supercritical fluid extraction, flocculation, solar or drum drying), and non-mechanical ones, such as chemical (solvent extraction, osmotic shock) and/or enzymatic. An economic evaluation showed that operational and energy consumption costs for these are in the range $0.2-5 € / \mathrm{kg}$ algae [68]. Algal cell walls are thick and rigid due to the existence of covalent bonds, hydrogen bonds and van der Waals forces interaction among the molecules. This makes algal cell disintegration and intracellular compounds extraction difficult and costly and identifies these steps as the main bottlenecks in the industrialization of microalgae exploitation in biorefinery [70]. Table 2 summarizes results achieved in lipid extraction from various algal species by conventional and other technologies, including PEF.

Table 2. Summary of conventional and novel methods for lipid extraction from algal cells.

\begin{tabular}{|c|c|c|c|c|}
\hline Method & Operating Conditions & Microalgal Strain & $\begin{array}{l}\text { Lipid Extraction Yield } \\
(\% \mathrm{wt})\end{array}$ & Reference \\
\hline Ultrasound + solvent & $\begin{array}{l}\text { Ultrasonication in ice/ } \\
\text { water bath for } 20 \mathrm{~min}\end{array}$ & $\begin{array}{l}\text { Chlorella minutissima, } \\
\text { Thalassiosira fluviatiis, } \\
\text { Thalassiosira pseudonana }\end{array}$ & $15.5-40.3$ & {$[71]$} \\
\hline Ultrasound + solvent & $\begin{array}{c}\text { US: } 40 \mathrm{kHz}, 2.68 \mathrm{~W} / \mathrm{m} 2,25^{\circ} \mathrm{C} \\
\text { 2-step extraction with: } \\
\text { 1) } \mathrm{CH}_{3} \mathrm{OH}+\mathrm{CHCl}_{3} / \mathrm{US}_{40 \min } \text { or } \\
\mathrm{CH} 3 \mathrm{OH} / \mathrm{US}_{3 \min } \text { or } \mathrm{C}_{3} \mathrm{H}_{7} \mathrm{OH} / \mathrm{US}_{4 \mathrm{~min}} \\
\text { 2) } \mathrm{CHCl}_{3}+\mathrm{Na}_{2} \mathrm{SO}_{4} / \mathrm{US}_{20 \text { min }} \text { or } \\
\mathrm{CH}_{2} \mathrm{Cl}_{2} / \mathrm{US}_{27 \text { min }} \text { or } \mathrm{C}_{6} \mathrm{H}_{14} / \mathrm{US}_{56 \mathrm{~min}}\end{array}$ & Chlorella vulgaris & $2.2-52.5$ & {$[72]$} \\
\hline Ultrasound + Soxlet & $\begin{array}{c}40 \mathrm{kHz}, 2.68 \mathrm{~W} / \mathrm{m}^{2} \\
\text { Soxhlet for } 8 \mathrm{~h} \text { with acetone }\end{array}$ & Chlorella vulgaris & 1.8 & [72] \\
\hline MW + solvent & $\begin{array}{c}2.45 \mathrm{GHz}, 400 \mathrm{~W}_{30 \min } \\
\mathrm{CH}_{3} \mathrm{OH}+\mathrm{CHCl}_{3}\end{array}$ & Chlorella pyrenoidosa & 19.03 & {$[73]$} \\
\hline
\end{tabular}


Table 2. Cont.

\begin{tabular}{|c|c|c|c|c|}
\hline Method & Operating Conditions & Microalgal Strain & $\begin{array}{l}\text { Lipid Extraction Yield } \\
\text { (\% wt) }\end{array}$ & Reference \\
\hline MW + solvent & $\begin{array}{c}500 \mathrm{~W}_{5 \min }, 65^{\circ} \mathrm{C} \\
\text { Various extraction methods (2 stage) with } \\
\mathrm{CH}_{3} \mathrm{OH}, \mathrm{CHCl}_{3}+\mathrm{Na}_{2} \mathrm{SO}_{4}, \mathrm{CH}_{2} \mathrm{Cl}_{2} \\
\mathrm{C}_{3} \mathrm{H}_{7} \mathrm{OH}, \mathrm{C}_{6} \mathrm{H}_{14}\end{array}$ & $\begin{array}{l}\text { Nannochloropsis sp. } \\
\text { Tetraselmis sp. }\end{array}$ & $\begin{array}{l}4.2-8.4 \\
5.4-8.2\end{array}$ & {$[74]$} \\
\hline $\begin{array}{l}\text { Osmotic shock + } \\
\text { solvent }\end{array}$ & $\begin{array}{c}10 \% \mathrm{NaCl}_{4} 4 \mathrm{~h}, \text { then } \\
\mathrm{CHCl}_{3}+\mathrm{CH}_{3} \mathrm{OH}\end{array}$ & $\begin{array}{c}\text { Botryococcus sp. } \\
\text { Scenedesmus sp./Chlorella vulgaris }\end{array}$ & $\begin{array}{l}\sim 11 \\
\sim 8\end{array}$ & [75] \\
\hline Solvent extraction & $\mathrm{CHCl}_{3}+\mathrm{CH}_{3} \mathrm{OH}$ & $\begin{array}{l}\text { Isochrysis galbana, Nannochloropis } \\
\text { gaditana, Nannochloropsis sp., } \\
\text { Phaeodactylum tricornutum }\end{array}$ & $17.8-30.2$ & [76] \\
\hline $\begin{array}{l}\text { Bead-beating }+ \\
\text { Supercritical } \mathrm{CO}_{2} \\
\text { extraction }\end{array}$ & $\begin{array}{l}1500 \mathrm{rpm} \text { for } 5 \mathrm{~min} . \\
\text { SC-CO2: } 306 \text { bar, } 60^{\circ} \mathrm{C}, 6 \mathrm{~h}\end{array}$ & Pavlova sp. & 17.9 & [77] \\
\hline Enzymatic & $\begin{array}{c}37^{\circ} \mathrm{C} \text { for } 2 \mathrm{~h} \text { with: } \\
\text { Viscozyme or Papain or Proteinase K or } \\
\text { Driselase }\end{array}$ & $\begin{array}{l}\text { Phaeodactylum tricornutum } \\
\text { Thalassiosira pseudonana }\end{array}$ & $\begin{array}{c}92-104 \\
88\end{array}$ & [78] \\
\hline Enzymatic + solvent & $\begin{array}{c}\text { Papain, } 37^{\circ} \mathrm{C}, 2 \mathrm{~h} \text { plus } \\
\mathrm{C}_{7} \mathrm{H}_{16} \text { or } \\
\mathrm{C}_{7} \mathrm{H}_{16}+\mathrm{C}_{3} \mathrm{H}_{7} \mathrm{OH}\end{array}$ & Phaeodactylum tricornutum & $56-96$ & [78] \\
\hline Enzymatic + solvent & $\begin{array}{c}\text { Cellulase } 60{ }^{\circ} \mathrm{C}, 4.6 \mathrm{pH}, 72 \mathrm{~h} \\
\text { then } \mathrm{n}-\mathrm{C}_{6} \mathrm{H}_{14}, 28{ }^{\circ} \mathrm{C}\end{array}$ & Chlorella sp. & 10.6 & [79] \\
\hline Electric Field lysis & $0.3 \mathrm{~A}, 60 \mathrm{~min}, 14.3-30.7 \mathrm{~V} / \mathrm{cm}$ & Chlorella vulgaris & $2.08-3.7$ & {$[80]$} \\
\hline $\begin{array}{l}\text { Fenton Reaction }+ \\
\text { solvent }\end{array}$ & $\mathrm{H}_{2} \mathrm{O}_{2}+\mathrm{n}-\mathrm{C}_{6} \mathrm{H}_{14}$ & Chlorella vulgaris & $9.24-17.37$ & {$[81]$} \\
\hline PEF & $2.7 \mathrm{kV} / \mathrm{cm}, \mathrm{W}=14.4 \mathrm{~kJ} / \mathrm{L}$ & Chlorella vulgaris & 22 & {$[82]$} \\
\hline PEF & $35 \mathrm{kV} / \mathrm{cm}, 200 \mathrm{~kJ} / \mathrm{kg}_{\mathrm{ss}}$ & $\begin{array}{l}\text { Auxenochlorella } \\
\text { protothecoides }\end{array}$ & 22 & [10] \\
\hline PEF + solvent & $>35 \mathrm{kWh} / \mathrm{m}^{3}$, Isopropanol & Synechocystis PCC 6803 & $25-75$ & [83] \\
\hline
\end{tabular}

Algal extraction technologies reported and tested include freeze-thaw, bead-milling, ultrasonic, chemical, and osmotic shock. Application of these methods are however limited due to high energetic demand or operational difficulties. Wet extraction methods are normally cheaper than dry ones (require no energy to dry biomass), however, research showed that chemical wet lipid extraction with solvents (e.g., chloroform: methanol) can show efficiency reduction by up to a third [84]. Unlike in traditional cell disruption technology, which completely disintegrated cell wall membranes and released all cell components, electroporation can enable highly selective extraction of intracellular products, maintaining their original quality and subsequent fractionation of pure extracts [85].

In addition to energy uses, many microalgae-derived products are also sold to commodity markets, competing with products from conventional sources. The potential market has been conservatively estimated to be in the range of \$500-1000 million/year with rapid growth and consists of two main areas: biofuels and "everything else", which includes food (for both animals and humans), nutritional supplements (e.g., omega-3), cosmetics, fertilizers, and many other specialty chemicals, with the non-biofuels category actually commanding the highest commercial prices. Decreasing extraction costs has been recognized by the algal industry as one of the most significant challenges to these products' commercialization [86]. In the last years, sales of algal-based products have grown significantly, and at the same time wide industrial interest in PEF application has arisen, with special focus on increasing the cost-effectiveness of algal-derived products extraction. Similar to the key requirements for sludge processing technology, lipid and other constituents' extraction technologies must include high efficiency (in terms of time and energy), non-reactivity with the compounds of interest, environmental safety, and relatively low cost (in terms of equipment and operation). 
Extraction of specialty products from lignocellulosic biomasses from plants and crop residues (e.g., phenolic compounds, and polyhydroxyalkanoates, PHAs, one of the most promising degradable alternatives to plastic from fossil sources) by biorefinery is becoming industrially attractive, as these are widely available and potentially carbon-neutral sustainable feedstocks. LCB is already widely used for biogas production in co-digestion facilities, and may be converted to other biofuels or market-valuable extracts. LCB is composed of carbohydrate polymers (cellulose, hemicellulose) linked to an aromatic polymer (lignin); its complex structure makes its depolymerization, necessary to perform valuable compounds recovery, quite challenging. PEF-assisted polyphenols extraction from spruce bark biomass at electric field exposure of $20 \mathrm{kV} / \mathrm{cm}$ at $\mathrm{pH} 12$ increased yields eightfolds compared to non-PEF-assisted samples, PEF being a good alternative to high temperature solvent extraction and grinding processes, with lower reported energy consumption $(3.2 \mathrm{~kJ} / \mathrm{g}$ vs. $8.75 \mathrm{~kJ} / \mathrm{g})$ [87]. Table 3 summarizes reported PEF applications in biorefinery of various feedstocks.

Table 3. Reported PEF applications in biomasses biorefinery.

\begin{tabular}{|c|c|c|c|}
\hline Feedstock & Purpose & Description & Reference \\
\hline \multirow{2}{*}{$\begin{array}{c}\text { Algae } \\
\text { A. protothecoides, C. vulgaris, } \\
\text { N. salina }\end{array}$} & \multirow{2}{*}{ Protein extraction } & $\mathrm{E}=3-34 \mathrm{kV} / \mathrm{cm}$ & \\
\hline & & Protein extraction yields: $3.5-5 \mu \mathrm{g}$ protein $/ 100 \mu \mathrm{L}$ & {$[88]$} \\
\hline $\begin{array}{l}\text { Foodcrops } \\
\text { residuals }\end{array}$ & $\begin{array}{l}\text { High value products } \\
\text { extraction }\end{array}$ & $\begin{array}{c}\mathrm{E}=5-20 \mathrm{kV} / \mathrm{cm} \\
>50 \% \text { energy saving compared with traditional } \\
\text { methods, extraction yield of polyphenols } \\
\text { increased by } 150 \%\end{array}$ & {$[89,90]$} \\
\hline LCB & Biofuel production & $\mathrm{E}=8-10 \mathrm{kV} / \mathrm{cm}$ & [91] \\
\hline
\end{tabular}

On a final note, PEF application for the improvement of algal biomass cultivation was reported: genetic modification (delivery) assisted by pulse electric field was used to obtain stable transformants of both wall-less and walled strains of microalgae Chlamydomonas reinhardtii, Chlorella ellipsoidea, and Dunaliella salina [92]. This technology was also implemented to optimize industrial microalgae production by controlling protozoa contamination (predators that can substantially jeopardize algal productivity) of an industrial microalgae photobioreactor. A contaminated culture was treated at $900 \mathrm{~V} / \mathrm{cm}$ with $65 \mu$ s pulses of $50 \mathrm{~Hz}$, reducing the active protozoan population by $87 \%$ after $6 \mathrm{~h}$, and completely after a few days of normal cultivation, showing that PEF is effective on the selective elimination of protozoa by inflicting on these organisms cell rupture, growth inhibition, or death without affecting microalgae productivity [93].

\section{Discussion}

PEF technology appears to have substantial promises in improving organic residues (wastewater and biomasses processing) management, even if data available are currently limited to the most interesting commercial sector of microalgae biorefinery. Data are not yet conclusive, with occasionally contrasting results: in one application $(E=9.6 \mathrm{kV} / \mathrm{cm})$ for C. zofingiensis lysis, a cost of $\$ 2.69 /$ barrel was estimated for pretreatment, over an order of magnitude lower than the cost of a thermal process ( $\$ 40 \mathrm{USD} /$ barrel) under the same assumptions [94]. Assuming that subsequent compounds' extraction costs are similar after either process, PEF would result over an order of magnitude cheaper. Other researchers, however, estimated that PEF efficiencies in terms of absolute yield and energy input were currently lower than those of another established process, such as bead milling [95]. Process efficiency seems to be affected by the specific experimental approach (substrate, operating conditions, and objective), with a wide range of results obtained, as summarized in the tables above.

Beside some apparent advantages, PEF technology also has a number of potential limitations, the most important one being the high initial capital investment. Although 
economic issues are seldom addressed in published literature, a few sources indicate that commercial PEF units manufactured for industrial scale (mainly food industry, medical, or biorefinery) applications are available at prices ranging from a few tens to hundreds of thousand dollars [22]. Furthermore, many technologies that look promising when tested at the small scale in new fields may not be effective or sustainable at large scale in continuous processes [96]. It should also be remarked that most studies focusing on biogas production or extraction processes improvement do not include the determination of realistic specific energy balances (e.g., $\mathrm{kWh} / \mathrm{m}^{3}$ or $\mathrm{t}$ sludge). Usually, these estimates refer just to the pretreatment itself and do not account for the process as a whole, which may be affected by other inputs [97].

\section{Conclusions}

This paper summarized studies on the application of pulsed electric field technology for wastewater and biomass residues' improved valorization for renewable fuels production and recovery of nutrients and value-added products. PEF pretreatment leads to release of intracellular embedded substances from substrate cells, facilitating the contact between these and external bacteria for conversion to methane or their extraction for further processing. These PEF applications represent an attractive approach for future valorization of sewage sludge and biomasses, since they have demonstrated great promises in the improvement of existing processes' yields, however, they also constitute a great challenge as PEF pretreatments, now commonly used in the food and medical industry and in some biorefinery applications, are still in infancy in the specific residues valorization sector. Commercial equipment has been successfully developed for food industry applications (mils and juices pasteurization, potato chips, and other snacks pre-processing), which may have economic margins similar to those of the residues recovery sector, however, it may not be suitable for the latter due to the properties of the media involved. Further research and development on specific equipment adapted to each substrate and on its field performance is needed.

The determination of closed energy balances for the entire processes involved, and not limited to the pretreatment phase itself, is also needed on each specific case study in order to assess the impact of PEF processing on residues' valorization.

Funding: This research received no external funding.

Institutional Review Board Statement: Not applicable.

Informed Consent Statement: Not applicable.

Data Availability Statement: Not applicable.

Conflicts of Interest: The author declares no conflict of interest.

\section{References}

1. Capodaglio, A.G.; Olsson, G. Energy Issues in Sustainable Urban Wastewater Management: Use, Demand Reduction and Recovery in the Urban Water Cycle. Sustainability 2020, 12, 266. [CrossRef]

2. Shizas, I.; Bagley, D.M. Experimental Determination of Energy Content of Unknown Organics in Municipal Wastewater Streams. J. Energy Eng. 2004, 130, 45-53. [CrossRef]

3. Sersa, G.; Cemazar, M. Tissue Reactions to Electroporation and Electrochemotherapy: Vascular Effects that have Implications in Tumor Treatment. In Proceedings of the 1st World Congress on Electroporation and Pulsed Electric Fields in Biology, Medicine and Food \& Environmental Technologies, IFMBE, Portorož, Slovenia, 6-10 September 2015.

4. Toepfl, S.; Heinz, V.; Knorr, D. Overview of pulsed electric field processing for food. In Emerging Technologies for Food Processing: An Overview; Elsevier Ltd.: New York, NY, USA, 2005; pp. 69-97.

5. Postma, P.; Pataro, G.; Capitoli, M.; Barbosa, M.; Wijffels, R.; Eppink, M.; Olivieri, G.; Ferrari, G. Selective extraction of intracellular components from the microalga Chlorella vulgaris by combined pulsed electric field-temperature treatment. Bioresour. Technol. 2016, 203, 80-88. [CrossRef]

6. Golberg, A.; Sack, M.; Teissie, J.; Pataro, G.; Pliquett, U.; Saulis, G.; Stefan, T.; Miklavcic, D.; Vorobiev, E.; Frey, W. Energy-efficient biomass processing with pulsed electric fields for bioeconomy and sustainable development. Biotechnol. Biofuels 2016, 9, 1-22. [CrossRef] 
7. Zimmermann, U.; Pilwat, G.; Riemann, F. Dielectric breakdown of cell membranes. Biophys. J. 1974, 14, 881-899. [CrossRef]

8. Kotnik, T.; Miklavčič, D. Theoretical evaluation of voltage inducement on internal membranes of biological cells exposed to electric fields. Biophys. J. 2006, 90, 480-491. [CrossRef]

9. Saulis, G.; Saulè, R. Size of the pores created by an electric pulse: Microsecond vs millisecond pulses. Biochim. et Biophys. Acta (BBA)-Biomembr. 2012, 1818, 3032-3039. [CrossRef]

10. Eing, C.J.; Goettel, M.; Straessner, R.; Gusbeth, C.; Frey, W. Pulsed electric field treatment of microalgae-Benefits for microalgae biomass processing. IEEE Trans. Plasma Sci. 2013, 41, 2901-2907. [CrossRef]

11. Buchmann, L.; Brändle, I.; Haberkorn, I.; Hiestand, M.; Mathys, A. Pulsed electric field based cyclic protein extraction of microalgae towards closed-loop biorefinery concepts. Bioresour. Technol. 2019, 291, 121870. [CrossRef]

12. Gusbeth, C.; Eing, C.; Goettel, M.; Frey, W. Boost of algae growth by ultra short pulsed electric field treatment. In Proceedings of the Abstracts IEEE International Conference on Plasma Science (ICOPS), San Francisco, CA, USA, 16-21 June 2013.

13. Buchmann, L.; Mathys, A. Perspective on Pulsed Electric Field Treatment in the Bio-based Industry. Front. Bioeng. Biotechnol. 2019. [CrossRef]

14. US EPA. Wastewater Treatment by Pulsed Electric Field Processing; Phase I (2002); Final Report; Contract Number: 68D02089; Small Business Innovation Research (SBIR): Washington, DC, USA, 2002.

15. Salerno, M.B.; Lee, H.S.; Parameswaran, P.; Rittmann, B.E. Using a Pulsed Electric Field as a Pretreatment for Improved Biosolids Digestion and Methanogenesis. Water Environ. Res. 2009, 81, 831-839. [CrossRef] [PubMed]

16. Zhang, C.; Liang, L.; Wang, Y.; Hu, X. Enhancement of the ANAMMOX bacteria activity and granule stability through pulsed electric field at a lower temperature $\left(16 \pm 1^{\circ} \mathrm{C}\right)$. Bioresour. Technol. 2019, 292, 1219602. [CrossRef] [PubMed]

17. Han, S.F.; Jin, W.; Yang, Q.; Abomohra, A.E.F.; Zhou, X.; Tu, R.; Chen, C.; Xie, G.J.; Wang, Q. Application of pulse electric field pretreatment for enhancing lipid extraction from Chlorella pyrenoidosa grown in wastewater. Renew. Energy 2019, 133, 233-239. [CrossRef]

18. Kotnik, T.; Kramar, P.; Pucihar, G.; Miklavcic, D. Cell membrane electroporation-Part 1: The phenomenon. IEEE Electr. Insul. M. 2012, 28, 14-23. [CrossRef]

19. Ricci, A.; Parpinello, G.P.; Versari, A. Recent Advances and Applications of Pulsed Electric Fields (PEF) to improve polyphenol extraction and color release during red winemaking. Beverages 2018, 4, 18. [CrossRef]

20. Bot, F.; Verkerk, R.; Mastwijk, H.; Anese, M.; Fogliano, V.; Capuano, E. The effect of pulsed electric fields on carotenoids bioaccessibility: The role of tomato matrix. Food Chem. 2017, 240, 415-421. [CrossRef]

21. El Achkar, J.H.; Lendormi, T.; Salameh, D.; Louka, N.; Maroun, R.G.; Lanoisellé, J.-L.; Hobaika, Z. Influence of pretreatment conditions on lignocellulosic fractions and methane production from grape pomace. Bioresour. Technol. 2018, 247, 881-889. [CrossRef]

22. Kovacic, D.; Rupcic, S.; Kralik, D.; Jovicic, D.; Spajic, R.; Tišma, M. Pulsed electric field: An emerging pretreatment technology in a biogas production. Waste Manag. 2021, 120, 467-483. [CrossRef]

23. Capodaglio, A.G.; Callegari, A. Feedstock and process influence on biodiesel produced from waste sewage sludge. J. Environ. Manag. 2018, 216, 176-182. [CrossRef]

24. Skowrońska, M.; Bielińska, E.J.; Szymański, K.; Futa, B.; Antonkiewicz, J.; Kołodziej, B. An integrated assessment of the long-term impact of municipal sewage sludge on the chemical and biological properties of soil. Catena 2020, 189, 104484. [CrossRef]

25. Henkanatte-Gedera, M.S.; Selvaratnam, T.; Caskan, N.; Nirmalakhandan, N.; Van Voorhies, W.; Lammers, P.J. Algal-based, single-step treatment of urban wastewaters. Bioresour. Technol. 2015, 189, 273-278. [CrossRef]

26. Callegari, A.; Bolognesi, S.; Cecconet, D.; Capodaglio, A.G. Production technologies, current role, and future prospects of biofuels feedstocks: A state-of-the-art review. Crit. Rev. Environ. Sci. Technol. 2020, 50, 384-436. [CrossRef]

27. Li, M.; Pu, Y.; Ragauskas, A.J. Current understanding of the correlation of lignin structure with biomass recalcitrance. Front. Chem. 2016, 4, 45. [CrossRef]

28. Salerno, M.; Nurdogan, Y.; Lundquist, T.J. Biogas Production from Algae Biomass Harvested at Wastewater Treatment Ponds; BIO-098023; American Society of Agricultural and Biological Engineers: St. Joseph, MI, USA, 2009.

29. Su, Y.; Mennerich, A.; Urban, B. Synergistic cooperation between wastewater-born algae and activated sludge for wastewater treatment: Influence of algae and sludge inoculation ratios. Bioresour. Technol. 2012, 105, 67-73. [CrossRef]

30. Raboni, M.; Viotti, P.; Capodaglio, A.G. A comprehensive analysis of the current and future role of biofuels for transport in the European Union (EU). Rev. Ambiente Agua 2015, 10, 9-21. [CrossRef]

31. Capodaglio, A.G.; Callegari, A.; Lopez, M.V. European framework for the diffusion of biogas uses: Emerging technologies, acceptance, incentive strategies, and institutional-regulatory support. Sustainability 2016, 8, 298. [CrossRef]

32. Capodaglio, A.G.; Ranieri, E.; Torretta, V. Process enhancement for maximization of methane production in codigestion biogas plants. Manag. Environ. Qual. Intern. J. 2016, 27, 289-298. [CrossRef]

33. Park, C.; Lee, C.; Kim, S.; Chen, Y.; Chase, H.A. Upgrading of anaerobic digestion by incorporating two different hydrolysis processes. J. Biosci. Bioeng. 2005, 100, 164-167. [CrossRef] [PubMed]

34. Kavitha, S.; Banu, J.R.; Kumar, V.K.; Rajkumar, M. Improving the biogas production performance of municipal waste activated sludge via disperser induced microwave disintegration. Bioresour. Technol. 2016, 217, 21-27. [CrossRef] [PubMed]

35. Ebenezer, A.V.; Kaliappan, S.; Adish Kumar, S.; Yeom, I.T.; Rajesh Banu, J. Influence of deflocculation on microwave disintegration and anaerobic biodegradability of waste activated sludge. Bioresour. Technol. 2015, 185, 194-201. [CrossRef] [PubMed] 
36. Gabric, D.; Barba, F.; Roohinejad, S.; Gharibzahedi, S.M.T.; Radojcin, M.; Putnik, P.; Kovacevic, D.B. Pulsed electric fields as an alternative to thermal processing for preservation of nutritive and physicochemical properties of beverages: A review. J. Food Process Eng. 2018, 41, 12638. [CrossRef]

37. Safavi, S.M.; Unnthorsson, R. Methane yield enhancement via electroporation of organic waste. Waste Manag. 2017, 66, 61-69. [CrossRef] [PubMed]

38. Lee, I.-S.; Rittmann, B.E. Effect of low solids retention time and focused pulsed pre-treatment on anaerobic digestion of waste activated sludge. Bioresour. Technol. 2011, 102, 2542-2548. [CrossRef] [PubMed]

39. Houtmeyers, S.; Degrève, J.; Willems, K.; Dewil, R.; Appels, L. Comparing the influence of low power ultrasonic and microwave pre-treatments on the solubilisation and semi-continuous anaerobic digestion of waste activated sludge. Bioresour. Technol. 2014, 171, 44-49. [CrossRef]

40. Garoma, T.; Shackelford, T. Electroporation of Chlorella vulgaris to enhance biomethane production. Bioresour. Technol. 2014, 169, 778-783. [CrossRef]

41. Lindmark, J.; Lagerkvist, A.; Nilsson, E.; Carlsson, M.; Thorin, E.; Dahlquist, E. Evaluating the Effects of Electroporation Pre-treatment on the Biogas Yield from Ley Crop Silage. Appl. Biochem. Biotechnol. 2014, 174, 2616-2625. [CrossRef] [PubMed]

42. Wang, B.; Chen, T.; Qin, X.; Wu, Q.; Zhao, Y.; Bai, S.; Peng, W.; Feng, B. Effect of high-voltage pulsed electric field (HPEF) pretreatment on biogas production rates of hybrid Pennisetum by anaerobic fermentation. Nat. Gas Ind. B 2018, 5, 48-53. [CrossRef]

43. Kovacic, Đ.; Kralik, D.; Rupcic, S.; Jovicic, D.; Spajic, R.; Tišma, M. Electroporation of harvest residues for enhanced biogas production in anaerobic co-digestion with dairy cow manure. Bioresour. Technol. 2019, 274, 215-224. [CrossRef]

44. Gao, Y.; Deng, Y.D.; Zhang, J.; Liu, F.J.; Men, Y.K.; Wang, Z.; Du, B.X. Effect of pulsed electric field on pretreatment efficiency in anaerobic digestion of excess sludge. In Proceedings of the 11th International Conference on the Properties and Applications of Dielectric Materials (ICPADM), Xi'an, China, 20-24 May 2015. [CrossRef]

45. Kopplow, O.; Barjenbruch, M.; Heinz, V. Sludge pre-treatment with pulsed electric fields. Water Sci. Technol. 2004, 49, 123-129. [CrossRef]

46. Choi, H.; Jeong, S.-W.; Chung, Y.-J. Enhanced anaerobic gas production of waste activated sludge pretreated by pulse power technique. Bioresour. Technol. 2006, 97, 198-203. [CrossRef]

47. Ki, D.; Parameswaran, P.; Rittmann, B.E.; Torres, C.I. Effect of pulsed electric field pretreatment on primary sludge for enhanced bioavailability and energy capture. Environ. Eng. Sci. 2015, 32, 831-837. [CrossRef]

48. Rittmann, B.E.; Lee, H.; Zhang, H.; Alder, J.; Banaszak, J.E.; Lopez, R. Full-scale application of focused-pulsed pre-treatment for improving biosolids digestion and conversion to methane. Water Sci. Technol. 2008, 58, 1895-1901. [CrossRef] [PubMed]

49. Zhang, H.; Banaszak, J.E.; Parameswaran, P.; Alder, J.; Krajmalnik-Brown, R.; Rittmann, B.E. Focused-Pulsed sludge pre-treatment increases the bacterial diversity and relative abundance of acetoclastic methanogens in a full-scale anaerobic digester. Water Res. 2009, 43, 4517-4526. [CrossRef] [PubMed]

50. Daneshgar, S.; Callegari, A.; Capodaglio, A.G.; Vaccari, D. The Potential Phosphorus Crisis: Resource Conservation and Possible Escape Technologies: A Review. Resources 2018, 7, 37. [CrossRef]

51. Marti, N.; Ferrer, J.; Seco, A.; Bouzas, A. Optimisation of sludge line management to enhance phosphorus recovery in WWTP. Water Res. 2008, 42, 4609-4618. [CrossRef]

52. Daneshgar, S.; Buttafava, A.; Capsoni, D.; Callegari, A.; Capodaglio, A.G. Impact of pH and Ionic Molar Ratios on Phosphorous Forms Precipitation and Recovery from Different Wastewater Sludges. Resources 2018, 7, 71. [CrossRef]

53. Tomei, M.C.; Stazi, V.; Daneshgar, S.; Capodaglio, A.G. Holistic Approach to Phosphorus Recovery from Urban Wastewater: Enhanced Biological Removal Combined with Precipitation. Sustainability 2020, 12, 575. [CrossRef]

54. Hu, P.; Liu, J.; Bao, H.; Wu, L.; Jiang, L.; Zou, L.; Wu, Y.; Qian, G.; Li, Y.-Y. Enhancing phosphorus release from waste activated sludge by combining high-voltage pulsed discharge pretreatment with anaerobic fermentation. J. Clean Prod. 2018, 196, $1044-1051$. [CrossRef]

55. Daneshgar, S.; Vanrolleghem, P.A.; Vaneeckhaute, C.; Buttafava, A.; Capodaglio, A.G. Optimization of P compounds recovery from aerobic sludge by chemical modeling and response surface methodology combination. Sci. Total Environ. 2019, 668, 668-677. [CrossRef]

56. Wang, O.; Wei, W.; Gong, Y.; Yu, Q.; Li, Q.; Sun, J.; Yuan, Z. Technologies for reducing sludge production in wastewater treatment plants: State of the art. Sci. Total Environ. 2017, 587, 510-521. [CrossRef] [PubMed]

57. Bai, H.; Zhu, R.; An, H.; Zhou, G.; Huang, H.; Ren, H.; Zhang, Y. Influence of wastewater sludge properties on the performance of electro-osmosis dewatering. Environ. Technol. 2018, 40, 2853-2863. [CrossRef]

58. Capodaglio, A.G.; Callegari, A. Energy use and recovery in wastewater treatment facilities. Renew. Energy Power Qual. J. 2020, 18, 425-430. [CrossRef]

59. Capodaglio, A.G.; Callegari, A.; Dondi, D. Microwave induced pyrolysis for production of sustainable biodiesel from waste sludges. Waste Biomass Valor. 2016, 7, 703-709. [CrossRef]

60. Bolognesi, S.; Bernardi, G.; Callegari, A.; Dondi, D.; Capodaglio, A.G. Biochar production from sewage sludge and microalgae mixtures: Properties, sustainability and possible role in circular economy. Biomass Conv. Bioref. 2021, 11, 289-299. [CrossRef]

61. Zhang, W.; Dong, B.; Dai, X. Mechanism analysis to improve sludge dewaterability during anaerobic digestion based on moisture distribution. Chemosphere 2019, 227, 247-255. [CrossRef] 
62. Bazhal, M.I.; Lebovka, N.I.; Vorobiev, E. Pulsed electric field treatment of apple tissue during compression for juice extraction. J. Food Eng. 2001, 50, 129-139. [CrossRef]

63. Boguniewicz-Zablocka, J.; Klosok-Bazan, I.; Capodaglio, A.G. Sustainable management of biological solids in small treatment plants: Overview of strategies and reuse options for a solar drying facility in Poland. Environ. Sci. Pollut. Res. 2020. [CrossRef]

64. Wang, H.; Brown, S.L.; Magesan, G.N.; Slade, A.H.; Quintern, M.; Clinton, P.W.; Payn, T.W. Technological options for the management of biosolids. Environ. Sci. Pollut. R. 2008, 15, 308-317. [CrossRef]

65. Kempkes, B.E. Pulsed electric field (PEF) systems for commercial food and juice processing, in Case Studies. In Novel Food Processing Technologies; Doona, C.J., Ed.; Woodhead Publishing: Sawston, UK, 2010; pp. 73-102. [CrossRef]

66. Chi, N.T.L.; Duc, P.A.; Mathimani, T.; Pugazhendhi, A. Evaluating the potential of green alga Chlorella sp. for high biomass and lipid production in biodiesel viewpoint. Biocatal. Agricult. Biotechnol. 2019, 17, 184-188. [CrossRef]

67. Eppink, M.H.M.; Olivieri, G.; Reith, H.; van den Berg, C.; Barbosa, M.J.; Wijffels, R.H. From current algae products to future biorefinery practices: A review. Adv. Biochem. Eng. Biotechnol. 2019, 166, 99-123. [CrossRef] [PubMed]

68. Fasaei, F.; Bitter, J.H.; Slegers, P.N.; van Boxtel, A.J.B. Techno-economic evaluation of microalgae harvesting and dewatering systems. Algal. Res. 2018, 31, 347-362. [CrossRef]

69. Smetana, S.; Sandmann, M.; Rohn, S.; Pleissner, D.; Heinz, V. Autotrophic and heterotrophic microalgae and cyanobacteria cultivation for food and feed: Life cycle assessment. Bioresour. Technol. 2017, 245, 162-170. [CrossRef]

70. Goettel, M.; Eing, C.; Gusbeth, C.; Straessner, R.; Frey, W. Pulsed electric field assisted extraction of intracellular valuables from microalgae. Algal Res. 2013, 2, 401-408. [CrossRef]

71. Neto, A.M.P.; de-Souza, R.A.S.; Leon-Nino, A.D.; da-Costa, J.D.A.; Tiburcio, R.S.; Nunes, T.A.; de-Mello, T.C.S.; Kanemoto, F.T.; Saldanha-Corrêa, F.M.P.; Gianesella, S.M.F. Improvement in microalgae lipid extraction using a sonication-assisted method. Renew. Energy 2013, 55, 525-531. [CrossRef]

72. Araujo, G.S.; Matos, L.J.B.L.; Fernandes, J.O.; Cartaxo, S.J.M.; Gonçalves, L.R.B.; Fernandes, F.A.N.; Farias, W.R.L. Extraction of lipids from microalgae by ultrasound application: Prospection of the optimal extraction method. Ultrason. Sonochem. 2013, 20, 95-98. [CrossRef] [PubMed]

73. Cheng, J.; Yu, T.; Li, T.; Zhou, J.; Cen, K. Using wet microalgae for direct biodiesel production via microwave Irradiation. Bioresour. Technol. 2013, 131, 531-535. [CrossRef]

74. Teo, C.L.; Idris, A. Enhancing the various solvent extraction method via microwave irradiation for extraction of lipids from marine microalgae in biodiesel production. Bioresour. Technol. 2014, 171, 477-481. [CrossRef] [PubMed]

75. Lee, J.Y.; Yoo, C.; Jun, S.Y.; Ahn, C.Y.; Oh, H.M. Comparison of several methods for effective lipid extraction from microalgae. Bioresour. Technol. 2010, 101, S75-S77. [CrossRef] [PubMed]

76. Ryckebosch, E.; Bruneel, C.; Termote-Verhalle, R.; Muylaert, K.; Foubert, I. Influence of extraction solvent system on extractability of lipid components from different microalgae species. Algal. Res. 2014, 3, 36-43. [CrossRef]

77. Cheng, C.H.; Dub, T.B.; Pi, H.C.; Jang, S.M.; Lin, Y.H.; Lee, H.T. Comparative study of lipid extraction from microalgae by organic solvent and supercritical CO2. Bioresour. Technol. 2011, 102, 10151-10153. [CrossRef]

78. Horst, I.; Parker, B.M.; Dennis, J.S.; Howe, C.J.; Scott, S.A.; Smith, A.G. Treatment of Phaeodactylum tricornutum cells with papain facilitates lipid extraction. J. Biotechnol. 2012, 162, 40-49. [CrossRef]

79. Fu, C.C.; Hung, T.C.; Chen, J.Y.; Su, C.H.; Wu, W.T. Hydrolysis of microalgae cell walls for production of reducing sugar and lipid extraction. Bioresour. Technol. 2010, 101, 8750-8754. [CrossRef]

80. Daghrir, R.; Igounet, L.; Brar, S.K.; Drogui, P. Novel electrochemical method for the recovery of lipids from microalgae for biodiesel production. J. Taiwan Inst. Chem. Eng. 2014, 45, 153-162. [CrossRef]

81. Steriti, A.; Rossi, R.; Concas, A.; Cao, G. A novel cell disruption technique to enhance lipid extraction from microalgae. Bioresour. Technol. 2014, 164, 70-77. [CrossRef]

82. Flisar, K.; Meglic, S.H.; Morelj, J.; Golob, J.; Miklavcic, D. Testing a prototype pulse generator for a continuous flow system and its use for E. coli inactivation and microalgae lipid extraction. Bioelectrochemistry 2014, 100, 44-51. [CrossRef] [PubMed]

83. Sheng, J.; Vannela, R.; Rittmann, B.E. Evaluation of cell-disruption effects of pulsed-electric-field treatment of Synechocystis PCC 6803. Environ. Sci. Technol. 2011, 45, 3795-3802. [CrossRef]

84. Halim, R.; Harun, R.; Danquah, M.K.; Webley, P.A. Microalgal cell disruption for biofuel development. Appl. Energy 2012, 91, 116-121. [CrossRef]

85. Carullo, D.; Abera, B.D.; Casazza, A.A.; Donsì, F.; Perego, P.; Ferrari, G.; Pataro, G. Effect of pulsed electric fields and high pressure homogenization on the aqueous extraction of intracellular compounds from the microalgae Chlorella vulgaris. Algal Res. 2018, 31, 60-69. [CrossRef]

86. Kempkes, M. Pulsed Electric Fields for Algal Extraction and Predator Control. In Handbook of Electroporation; Miklavcic, D., Ed.; Springer International Publishing AG: London, UK, 2016; pp. 1-15.

87. Bouras, M.; Grimi, N.; Bals, O.; Vorobiev, E. Impact of electrical treatment on the extraction of polyphenol from Norway spruce bark. Ind. Crop. Products 2016, 80, 50-58. [CrossRef]

88. Coustets, M.; Al-Karablieh, N.; Thomsen, C.; Teissié, J. Flow process for electroextraction of total proteins from microalgae. J. Membr. Biol. 2013, 246, 751-760. [CrossRef] [PubMed]

89. Boussetta, N.; Vorobiev, E.; Le, L.H.; Cordin-Falcimaigne, A.; Lanoisellé, J.L. Application of electrical treatments in alcoholic solvent for polyphenols extraction from grape seeds. LWT Food Sci. Technol. 2012, 46, 127-134. [CrossRef] 
90. Boussetta, N.; Soichi, E.; Lanoisellé, J.L.; Vorobiev, E. Valorization of oilseed residues: Extraction of polyphenols from flaxseed hulls by pulsed electric fields. Ind. Crop. Prod. 2014, 52, 347-353. [CrossRef]

91. Kumar, P.; Barrett, D.M.; Delwiche, M.J.; Stroeve, P. Pulsed electric field pretreatment of switchgrass and wood chip species for biofuel production. Ind. Eng. Chem. Res. 2011, 50, 10996-11001. [CrossRef]

92. Brown, L.E.; Sprecher, S.L.; Keller, L.R. Introduction of exogenous DNA into Chlamydomonas reinhardtii by electroporation. Mol. Cell Biol. 1991, 11, 2328-2332. [CrossRef] [PubMed]

93. Rego, D.; Redondo, L.M.; Geraldes, V.; Costa, L.; Navalho, J.; Pereira, M.T. Control of predators in industrial scale microalgae cultures with Pulsed Electric Fields. Bioelectrochemistry 2015, 103, 60-64. [CrossRef] [PubMed]

94. Roth, I. Application of Pulsed Electric Fields to the Extraction of Oil from Microalgae; SBIR Final Report for IIP-1013814; National Science Foundation: Alexandria, VA, USA, 2011.

95. 'tLam, G.P.; Postma, P.R.; Fernandes, D.A.; Timmermans, R.A.H.; Vermuë, M.-H.; Barbosa, M.J.; Eppink, M.H.M.; Wijffelsad, R.H.; Olivieri, G. Pulsed Electric Field for protein release of the microalgae Chlorella vulgaris and Neochloris oleoabundans. Algal Res. 2017, 24, 181-187.

96. Bochmann, G.; Montgomery, L.F.R. Storage and pre-treatment of substrates for biogas production. In The Biogas Handbook; Wellinger, A., Murphy, J., Baxter, D., Eds.; Woodhead Publishing: Sawston, UK, 2013; pp. 85-103.

97. Cano, R.; Pérez-Elvira, S.I.; Fdz-Polanco, F. Energy feasibility study of sludge pretreatments: A review. Appl. Energy 2015, 149, 176-185. [CrossRef] 